\title{
Reflexões acerca da prescritibilidade nas ações de ressarcimento ao erário previstas no art. 37, $\$ 5^{\circ}$ da Constituição
}

\author{
Antonio Roberto Winter de Carvalho*
}

\section{Introdução}

A correta interpretação dos institutos supera o entendimento meramente descritivo, destacando a importância de se extrair a sua essência, especialmente quando se trata da Constituição, talvez exatamente por isso os "estudos de direito público, especialmente de direito constitucional, lograram avanços significativos no que se refere à interpretação e à aplicação das normas constitucionais" (Ávila, 2008:23).

Na peregrinação pelo entendimento e pela aplicação sistêmica do ordenamento jurídico vigente, em especial do texto da Constituição, percebe-se um ponto de intenso conflito interpretativo, despontando os mais diversos entendimentos acerca da prescrição ou da imprescritibilidade para o exercício do direito ao ressarcimento do erário pelo administrador público, com base na previsão inserta no art. 37, §5ํ da Carta Magna.

A Constituição Federal de 1988 evidenciou o instituto da prescrição como um instrumento garantidor da segurança jurídica e da paz social, uma vez que através

\footnotetext{
* Bacharel em direito, formado pela Pontifícia Universidade Católica de Minas Gerais (PUC-Minas). Pós-graduado lato sensu em direito tributário pelo Instituto de Educação Continuada (IEC/PUC-Minas). Membro do Instituto Brasileiro de Direito Tributário (IBDT), associado ao Conselho Nacional de Pesquisa e Pós-Graduação em Direito (Conpedi). Membro do Instituto de Hermenêutica Jurídica. Mestrando em direito público pela PUC-Minas/Universidade Estadual de Montes Claros (Unimontes). Master of Business Administration (MBA) em controladoria, finanças e auditoria tributária pela Fundação Getulio Vargas (FGV). Sócio e diretor do Escritório Assrauy Carvalho Consultores e Advogados.
} 
do citado instituto impede-se que a pena seja eternizada, especialmente no âmbito das ações de pretensão condenatória e indenizatória.

Art. 37. A administração pública direta e indireta de qualquer dos Poderes da União, dos Estados, do Distrito Federal e dos Municípios obedecerá aos princípios da legalidade, impessoalidade, moralidade, publicidade, eficiência e também ao seguinte:

[...]

§5º A Lei estabelecerá os prazos de prescrição para ilícitos praticados por qualquer agente, servidor ou não, que causem prejuízos ao erário, ressalvadas as respectivas ações de ressarcimento.

O exame do dispositivo supra se torna necessário com vistas a evidenciar o correto entendimento acerca da prescritibilidade ou não das ações de ressarcimento ao erário, como forma de promover a interpretação hermenêutica harmonizando-a com os princípios vetores do ordenamento jurídico, em que se extrai que o dispositivo constitucional retratado não trata da imprescritibilidade, pelo contrário, se refere à prescritibilidade dos ilícitos praticados por agentes, servidor ou não, que causarem prejuízos ao erário, excluindo da legislação complementar a apreciação das ações de ressarcimento.

Apesar de parte da doutrina assim interpretar, persiste outra corrente que entende que as ressalvas relativas às ações de ressarcimento levam ao entendimento de que essas são imprescritíveis, fato contrário ao entendimento exarado neste artigo. Por isso, à luz da teoria geral do direito público não seria possível aceitar a imprescritibilidade, vez que estaria inaugurado o conflito entre normas, em especial no dispositivo que reza a impossibilidade da instituição de penas de caráter perpétuo $(\mathrm{CF} / 88$, art. 5은 $\mathrm{XLVII}, a)$.

A antinomia no texto constitucional estaria instituída a partir do momento em que consideramos que a existência da prescrição é regra; portanto, não necessita estar expressa, ao passo que a exceção obrigatoriamente deve resultar de expressa não cabendo interpretação análoga ou extensiva.

Desta forma, à luz da teoria geral do direito e da jurisprudência aplicada, pretende-se demonstrar a incongruência do entendimento da imprescritibilidade, para ao final comprovar que as ações de ressarcimento ao erário são prescritíveis.

Considerar a imprescritibilidade como uma não exceção fere preceitos jurídicos institucionalmente garantidos, como a segurança jurídica e a não eternização das penas, que por sua vez encontram-se conectados diretamente com os direitos fundamentais. 


\section{A imprescritibilidade é a exceção à regra da prescrição}

Por analogia, por presunção ou extensivamente não se pode instituir a imprescritibilidade. A Constituição trata expressamente e restritivamente dos casos em que não existe prescrição, como ocorre nos casos de racismo e ação de grupos armados, grifados com a previsão de que "constitui crime inafiançável e imprescritível" (CF/88, art. 5으, XLII e XLIV), ademais com o texto constitucional no art. 5º, XLVII, em que sobressai que "não haverá penas de caráter perpétuo" e com princípio da prescritibilidade repousando sob o postulado da paz social e da segurança jurídica.

Humberto Ávila (2008:23) destaca que havendo colisão entre regras, estas devem ser consideradas de modo absoluto e apenas uma delas prevalecerá, ao passo que havendo conflitos entre princípios, estes podem ser graduados em face de seu conteúdo axiológico e diante dos preceitos basilares do ordenamento jurídico vigente, o que leva indubitavelmente ao entendimento de que a ressalva contida no art. 37, §5º , não pode ser interpretada extensivamente, sob pena de conduzir à invalidade da norma, eis que tal inserção confrontaria com todo o ordenamento jurídico vigente.

Superado o discurso acerca do conflito de princípios, defrontamos no campo das regras novo debate, eis que a interpretação extensiva da imprescritibilidade é destoante do texto constitucional exatamente por se tratar de uma exceção à regra.

A imprescritibilidade não pode ser presumida. Deve ser expressa e taxativa, sob pena de ofensa à previsão expressa do art. 5ํ, XLVII, em que sobressai o literal entendimento que "não haverá penas de caráter perpétuo", o que conduziria ao prevalecimento da norma mencionada supra e, por conseguinte, a inaplicabilidade do inciso V do art. 37 da Constituição de 1988, nos termos trazidos por Ávila.

Ávila (2008:23), interpretando Dworkin, leciona que as regras são aplicadas do modo "tudo ou nada" ("all-or-nothing"). Por sua vez, os princípios contêm uma dimensão de peso ("dimension of weight"), permitindo nos casos de colisão a sobreposição daquele com maior peso, sem, contudo, retirar sua validade.

A prescrição é a regra no ramo público e no ramo privado do ordenamento jurídico vigente, consagrando como regra o princípio da prescritibilidade repousando sobre o postulado da paz social e da segurança jurídica, que podem ser considerados institutos pétreos que ora se tornam princípios, ora são orientadores da aplicação de outras normas (postulados).

Ao regrar as relações, é possível estabelecer a paz social e a segurança jurídica dentro de um ambiente demarcado por limites muito bem definidos, onde a eventual exceção demarcatória não invalida a norma padrão. Exatamente por isso deve ser consubstanciada de forma clara e inconteste, sob o risco de criarmos constantes 
antinomias, em que uma norma passa a contradizer a outra levando ao risco da perda de institutos pétreos.

Existe uma eminente necessidade de se efetivar uma "clareza conceitual" (Ávila, 2008:88), com vistas ao exame com construção parametrizada e fiel ao texto da Constituição. Por isso, a imprescritibilidade deve ser entendida como uma exceção à regra e com tal, não se admite interpretações extensivas, devendo fazer constar expressamente a ressalva, sob o risco de se confrontar com a regra prevalente nos ramos públicos, privados e até mesmo ir de encontro a direitos fundamentalmente assegurados.

\section{Na Constituição e no direito privado}

O ordenamento jurídico nacional recepciona a prescrição como regra, uma vez que representa garantia a não perpetuação de um direito não exercido, portanto extinto pela inércia do seu titular negligente, devido ao lapso temporal previsto em lei que conduz ao perecimento dessa reserva de ação.

A prescrição por uma questão de ordem pública é necessária para a pacificação e segurança das relações sociais, pela certeza de que não se eternizou o direito de promover ações relativas a fatos pretéritos. Assim, a alteração no prazo para o exercício desse direito somente é possível quando expressamente constar no texto da Constituição em, sentido contrário, a regra "que seriam comprometidas diante da instabilidade de se possibilitar o exercício por prazo indeterminado" (Diniz, 1991:202), não cabendo interpretação extensiva, estando regulado no Código Civil nos arts. 205 e 206.

Para Pontes de Miranda (1971:131), a pretensão legal se extingue na prescrição; portanto, extingue o direito de ação para que o direito não "perdure por demasiado tempo à exigibilidade ou a acionabilidade", de modo que os prazos "correspondem à concepção da vida já ultrapassada".

Segundo ensinamentos de Savigny (2004), o fundamento da prescrição reside na necessidade de serem fixadas as relações jurídicas certas, insuscetíveis de dúvidas e controvérsias, encerrando-se a incerteza em determinado lapso temporal, exercendo de modo incontestável a natureza de instituto de ordem pública, em igual sentido assevera Hely Lopes Meirelles (1995:627), para quem as regras civis da prescrição são também aplicáveis ao direito administrativo: "a prescrição das ações da Fazenda Pública contra o particular é comum da lei civil ou comercial [...]".

O direito não exercido pelo titular inerte e negligente não pode perdurar indefinidamente, sob pena de forte e constante insegurança jurídica. Todas as pessoas jurídicas ou naturais, sejam elas públicas ou privadas, estão sujeitas aos efeitos da prescrição após o prazo legal para sua aplicação, conforme exprime Mattos 
(2002:147): “o instituto jurídico da prescrição tem o condão de sepultar as situações jurídicas que não foram exercidas por certo lapso de tempo".

Nesse sentido, o ordenamento jurídico há tempo consolidou o entendimento de que a imprescritibilidade do direito é uma questão excepcional, sendo aplicada em situações específicas, como em algumas ações de natureza declaratória, em que não se pode falar em negligência do interessado, como nas relativas ao direito à personalidade, nas ações de família, nas pretensões nascidas das relações de vizinhança, dos direitos facultativos ou potestativos.

A doutrina e a legislação vigentes são uníssonas em entender que a pretensão reparatória e condenatória de danos se encontra excluída do rol das ações imprescritíveis e que a regra geral sobre o exercício do direito subjetivo da ação envolve a questão da prescrição, isto é, existe um prazo para que seja levada a pretensão do jurisdicionado ao Poder Judiciário.

Agnelo Amorim Filho (1960:7-8), ao avaliar as ações imprescritíveis, assevera que "as ações condenatórias podem prescrever, pois são elas as únicas por meio das quais se protegem os direitos suscetíveis de lesão". Subsumindo-se ao entendimento segundo o qual todas as ações de natureza reparatória de danos e condenatórias estão abarcadas pela regra geral da prescrição, tem-se que as ações de responsabilidade civil em face do Estado e a ação de regresso deste em face do administrador público são prescritíveis, respeitadas as formalidades aplicadas a cada um dos casos.

\section{No direito público}

Em compatibilidade com a Constituição de 1988 e com os ordenamentos vigentes no direito privado (especialmente no direito civil), o direito público através dos subramos administrativo, financeiro e tributário consagrou a prescrição como regra.

A prescrição quinquenal é a regra, como nos casos de improbidade administrativa, ${ }^{1}$ consubstanciada diante da necessidade de um arcabouço de segurança jurídica em face de transitoriedade e a alternância dos cargos na gestão pública, ante os riscos de extravio de documentos e a possibilidade de perseguições políticas.

A aplicação do prazo prescricional instituído pela Lei de Improbidade Administrativa atua como um contrapeso na realidade política nacional, uma vez

\footnotetext{
${ }^{1}$ Improbidade deriva do latim improbitis, o que significa má qualidade; logo, o conceito de ato de improbidade administrativa vem a ser todo aquele praticado pelo agente público, contrário ao ideal de defesa dos interesses da coletividade e da sociedade, sendo contrário à moral, à retidão da conduta diante do cargo e dos bons costumes no exercício do poder a este conferido, obtendo para si vantagens patrimoniais indevidas às expensas do erário, "mediante a concessão de obséquios e privilégios ilícitos" (Pazzaglini, 1998:194).
} 
que a contagem para o início do período prescricional somente se inicia após a desocupação do cargo, facilitando o acesso a documentos e garantindo a isenção do processo investigatório.

A Lei no 8.429, de 2 de junho de $1992,{ }^{2}$ veio suprir a lacuna existente, instituindo expressamente sansões aplicáveis aos agentes públicos nos casos de enriquecimento ilícito ${ }^{3}$ durante o exercício de mandato, cargo, emprego ou função desempenhada na administração pública direta, indireta ou fundacional, estabelecendo, conforme os demais ditames legais, a prescrição quinquenal (contados do término do mandato ou do cargo de função de confiança, devido às dificuldades em se descobrir a ilegalidade durante o desempenho da função).

\section{EMENTA: PROCESSUAL CIVIL. AÇÃO CIVIL PÚBLICA POR IMPROBI-} DADE ADMINISTRATIVA. PRESCRIÇÃO QUINQUENAL. ART. 23 DA LEI № 8.429/92. PRECEDENTES. 1. Recurso especial contra acórdão que afastou a preliminar de prescrição quinquenal levantada nos autos de ação civil pública por ato de improbidade administrativa, por considerá-la vintenária. 2. O art. 23 da Lei nº 8.429/92 estatui que "as ações destinadas a levar efeito às sanções previstas nesta Lei podem ser propostas até cinco anos após o término do exercício do mandato, de cargo em comissão ou de função de confiança. 3. In caso, ficou devidamente demonstrado que a prescrição quinquenal ocorreu, visto que o mandato do recorrente teve seu término em 31/12/1992 e a ação foi ajuizada apenas em 27/4/2001. Extinção do processo, com suporte no art. 269, IV, do CPC. 4. Precedentes desta Corte Superior: REsp. nº 680677/RS, Rel. Min. Humberto Martins, DJ de 2.2.2007; REsp. no 750187/RS, Rel. Min. Luiz Fux, DJ de 28.9.2006; REsp. no 665130/RS, 2 ${ }^{\underline{a}}$ Turma, Rel. Min. Castro Meira, DJ de 2.6.2006; REsp. no 681161/RS, Rel. Min. Francisco Falcão, DJ de 10.4.2006; REsp. no 803390/SP, Rel. Min. Francisco Falcão, DJ de 27.3.2006; REsp. n⿳⺈ 710701/RS, Rel ${ }^{\mathrm{a}}$ Min $^{\mathrm{a}}$ Eliana Calmon, DJ de 19.12.2005. 5. Recurso provido (STJ, 2005). ${ }^{4}$

Em similaridade com a ação de improbidade no direito público, encontramos a ação popular regulada pela Lei no 4.717 , de 1965, que tem consigo o dever de tutelar direito difuso, e como escopo precípuo a anulação e a declaração de nulidade

\footnotetext{
${ }^{2}$ Instituiu a chamada Lei de Improbidade Administrativa. Diário Oficial da União. Brasília, 2 jun. 1992.

${ }^{3}$ Silva (1997:113): “daí que nasce o sentido do locupletamento ilícito, que é o enriquecimento indevido, sem aparo legal, porque gera de ofensa ao patrimônio alheio. Nestas condições, assegura a lei ao prejudicado ir buscar das mãos do locupletador tudo com que se tenha enriquecido à sua custa em prejuízo dele".

${ }^{4}$ Superior Tribunal de Justiça. Recurso Especial no 890552/MG. Primeira Turma. Relator ministro José Delgado. Diário da Justiça, 22 mar. 2007, p. 315.
} 
de atos lesivos ao patrimônio público. Entretanto, conforme explícito em seu art. 21, o prazo prescricional para seu manejo é de cinco anos, contados da data de ocorrência da circunstância (ação ou omissão) lesiva ao patrimônio público.

Conquanto haja várias semelhanças entre a ação popular e a ação civil pública previstas na Constituição de 1988 e reguladas pela Lei no 7.347, de 1985, como as questões relativas à defesa de direitos difusos, atos de moralidade e controle dos atos administrativos, tutelados pelo art. 37 da Constituição, esta última não fixou em seu texto legal o prazo prescricional para o exercício da pretensão do direito de ação.

A ação civil pública, a ação popular e o mandado de segurança abordam atos de moralidade administrativa, "abrangem várias modalidades: o interesse geral, afeto a toda a sociedade; o interesse difuso, pertinente a um grupo de pessoas caracterizadas pela indeterminação e indivisibilidade" (Di Pietro, 2002:640), têm similitude de objeto e igualmente ficarão a mercê das regras de substituição processual.

Seu tratamento, destarte, deve ser rigorosamente o mesmo, especialmente no tocante à prescrição, apesar de não haver na Lei nº 7.347/85 estipulação do prazo prescricional, sendo esse entendimento manifestado pelo Superior Tribunal de Justiça ao julgar o REsp. no 406.545/SP: ${ }^{5}$

A Ação Civil Pública não veicula bem jurídico mais relevante para a coletividade do que a Ação Popular. Aliás, a bem da verdade, hodiernamente ambas as ações fazem parte de um microssistema de tutela dos direitos difusos onde se encartam a moralidade administrativa sob seus vários ângulos e facetas. Assim, à míngua de previsão do prazo prescricional para a propositura da Ação Civil Pública, inafastável a incidência da analogia legis, recomendando o prazo quinquenal para a prescrição das Ações Civis Públicas, tal como ocorre com a prescritibilidade da Ação Popular, porquanto $u b i$ eadem ratio ibi eadem legis dispositio.

Inexistindo a estipulação de previsão de prazo limite para o ajuizamento da ação civil pública, há de se considerar a aplicação da analogia legis (analogia da legislação) em estabelecer a prescrição em cinco anos nos moldes estabelecidos em igual situação pela ação popular, nas questões em que versar sobre direitos difusos em aspectos relativos à moralidade administrativa.

EMENTA: AÇÃO CIVIL PÚBLICA. IMPROBIDADE ADMINISTRATIVA. EX-PREFEITO. PRESCRIÇÃO. INOCORRÊNCIA. PRAZO QUINQUENAL

\footnotetext{
${ }^{5}$ Superior Tribunal de Justiça. REsp. nº 406.545/SP. Primeira Turma. Relator ministro Luiz Fux. Diário da Justiça, 9 dez. 2002, p. 292.
} 
RESPEITADO. I - Ação civil pública de improbidade administrativa ajuizada contra ex-prefeito cujo mandato se encerrou em 31/12/1996, sendo que a ação foi proposta em 20/11/2001. II - O prazo prescricional para o exercício dessa pretensão, fora dos casos de ressarcimento ao erário, é de cinco anos, contados do término do mandato do ex-prefeito, nos termos do que dispõe expressamente o art. 23, I, da Lei $n^{\underline{0}}$ 8.429/92. Precedentes: REsp. $n^{\underline{0}}$ 680.677/RS, Rel. Min. HUMBERTO MARTINS, DJ de 2/2/2007; REsp. no 689.875/RS, Rel. Min. JOSÉ DELGADO, DJ de 12/2/2007. III - Agravo Regimental improvido. ${ }^{6}$

Conforme demonstrados no ramo público do direito, a teoria e o processo se interagem tal como no ramo privado; por sua vez, ambos igualmente se compatibilizam respeitando as peculiaridades de cada um. Afinal, todos se convergem no mesmo ordenamento jurídico, ou seja, estão sob o manto do mesmo texto constitucional.

A Constituição de 1988 (art. $1^{\text {}}$ ) é solitária em sua hierarquia de texto máximo normativo da república, é consubstanciado no legítimo poder que "emana do povo", gerando seus efeitos em todas as demais normas de natureza hierarquicamente. Portanto, todas as leis infraconstitucionais preservam sua interdependência relativa, acorrentadas ao texto da Constituição, formando um sistema jurídico único, nos termos de Bobbio (1999:38):

A norma fundamental é o termo unificador das normas que compõem um ordenamento jurídico. Sem uma norma fundamental, as normas de que falamos até agora constituiriam um amontoado, não um ordenamento. Em outras palavras, por mais numerosas que sejam as fontes do direito num ordenamento complexo, tal ordenamento constitui uma unidade pelo fato de que, direta ou indiretamente, com voltas mais ou menos tortuosas, todas as fontes do direito podem ser remontadas a uma única norma. Devido à presença, num ordenamento jurídico, de normas superiores e inferiores, ele tem uma estrutura hierárquica. As normas de um ordenamento são dispostas em ordem hierárquica.

As relações de interdependência dentro do sistema jurídico atuam de modo que os institutos, mesmo conceitualmente independentes, se encontrem dependentes no exercício efetivo, o que provoca a inaplicabilidade de determinados institutos considerados como exceção à regra geral do ordenamento constitucional.

\footnotetext{
${ }^{6}$ Superior Tribunal de Justiça. Agravo Regimental no Recurso Especial 916.524/RS, 2007/0006918-0. Primeira Turma. Relator ministro Francisco Falcão. Diário da Justiça, 8 maio 2007, p. 406.
} 
O instituto da prescrição é a regra no ordenamento jurídico, é um meio pelo qual se garante a pacificação das relações jurídicas não exercidas pelo titular que se quedou inerte. Neste sentido, considerando remotamente possível a aplicação do instituto da imprescritibilidade no direito administrativo, inexistiriam ferramentas processuais hábeis para o exercício desse instituto, uma vez que todas elas prescreveriam em cinco anos.

\section{Nas ações de ressarcimento propriamente ditas}

A imprescritibilidade é uma exceção no ordenamento jurídico. Nessa condição, deve sempre ser fruto de uma expressa e literal identificação do conteúdo legal exposto, cabendo tão somente nesse caso o uso da interpretação restritiva. No ordenamento jurídico não existe previsão legal para a imprescritibilidade das ações de ressarcimento; portanto, prevalece a regra da prescrição.

Os crimes hediondos e/ou contra a vida são universalmente considerados ação de maior reprovação, de maior relevância, sendo punidos com maior rigor. Apesar disso, a eles não se aplica o instituto da imprescritibilidade. O texto da Constituição de 1988 destaca expressamente os casos excepcionais de imprescritibilidade, ressaltando como inafiançáveis e não sujeitos à prescrição em apenas duas hipóteses: os "crimes de racismo" (art. 5ํ, XLII) e a "ação de grupos armados contra a ordem e o Estado democrático" (art. 5ํ, XLIV).

Para a desembargadora Maria Tessler ${ }^{7}$ e para Erico Andrade ${ }_{,}^{8}$ entre outros vários doutrinadores, a imprescritibilidade é uma excepcionalidade; portanto, não se

\footnotetext{
7 “A Lei em comento envolve o debate sobre o princípio da segurança jurídica e o princípio da prescritibilidade das pretensões. A consagração do princípio da prescritibilidade repousa sobre o postulado da segurança jurídica. É reconhecido em lição exemplar por Pontes de Miranda, referindo que a prescrição atinge a todas as pretensões e ações, quer sejam direitos pessoais, reais, privados ou públicos. É a regra geral. O excepcional é a imprescritibilidade, e a Constituição admite duas hipóteses, o crime de racismo e o de terrorismo, grupos armados civis ou militares (art. 5ํㅡ, XLII, XLIV da CF/88). Conclui-se que a prescrição é o princípio informador do sistema jurídico pátrio na matéria" (Tessler, Marga Barth. Revista de Doutrina do Tribunal Regional Federal da $4^{\underline{a}}$ Região, no 53, 2006. Disponível em: <www.revistadedoutrina.trf4.gov.br>.

8 “O art. 37, §5º, da Constituição Federal parece, de forma indireta, declarar que a ação de ressarcimento de danos ao erário seria imprescritível. Todavia, esse entendimento mostra-se insustentável perante o próprio ordenamento jurídico vigente, pois a Constituição Federal estabelece, como direito e garantia fundamental, a vedação de penas perpétuas - art. 5․, XLVII, 'b'. Ora, no caso, a se entender imprescritível o ressarcimento, estar-se-ia criando a possibilidade, eterna, de se demandar, v.g., um tataraneto de um administrador improbo [...] Criada estaria, assim, em antinomia com a própria Constituição, uma pena perpétua. [...] essas antinomias ou conflitos aparentes de normas constitucionais são resolvidos mediante aplicação do princípio da concordância ou harmonização [...] o caso, certo que deve prevalecer o princípio contido no art. $5^{\circ}$, XLVII, ' $b$ ', CF, vez que situado no âmbito dos direitos e garantias fundamentais, sabidamente uma das cláusulas pétreas da Constituição, conforme se extrai do art. 60 , §4º , IV, CF. Tanto é certa a prevalência do direito fundamental de vedação de penas perpétuas sobre a norma do art. 37, §5ํㅡ, CF, que o art. 23 , I, da Lei 8.429/92, prevê a prescrição quinquenal para a aplicação de suas sanções - entre as quais se situa, obviamente, o perdimento de bens ou imposição de indenizar o erário" (Andrade, 2003:49).
} 
pode aceitar a extensão do instituto no intuito de se eternizar a aplicação da pena em confronto com uma cláusula pétrea que garanta o direito fundamental contido no art. 5', XLVII, $b$, da Constituição que "veda a pena de caráter perpétuo".

A atenta leitura do $\S 5^{\circ}$ do art. 37 permite concluir que esse dispositivo confere à lei infraconstitucional a competência para estabelecer o prazo de prescrição da ação, nos moldes e condições já estipulados pelo inciso I, do art. 23, da Lei n⿳o 8.429/92, no qual a "prescrição será de cinco anos após o término do exercício do mandato, do cargo em comissão ou da função de confiança, ao passo que o inciso II, nos casos de exercício de cargo efetivo ou emprego, remete para o mesmo prazo previsto na legislação específica para faltas disciplinares puníveis com demissão a bem do serviço público" (Meirelles, 2003:201).

As ações de ressarcimento ao erário na condição de ações condenatórias sujeitam-se aos efeitos da prescrição dentro do prazo de cinco anos, conforme dizeres de Nelson Nery Júnior (1999:742), sobretudo em face da exigência da segurança jurídica, ao respeito aos direitos fundamentais, e não poderia ser diferente, sob pena de criar a insegurança jurídica e romper com a paz social, o que à luz dos princípios constitucionais é inconcebível, razão pela qual não se falar em imprescritibilidade.

EMENTA: AÇÃO CIVIL PÚBLICA - RESSARCIMENTO - PRESCRIÇÃO. A responsabilidade civil do servidor público apura-se em caso de dano causado ao Estado ou de dano causado a terceiro. Em se tratando de dano causado ao Estado, a ação de improbidade submete-se à prescrição fixada em lei. ${ }^{9}$

Por meio de uma analogia para a determinação do prazo prescricional, nessa hipótese, a imprescritibilidade deve ser estabelecida com o direito administrativo. E este sempre teve por regra, quando não expressamente positivada, o prazo prescricional de cinco anos, valendo-se dessa regra tanto a favor da administração quanto contra ela, conforme se pode perceber também nos campos do direito, como no caso da Lei de Improbidade (art. 23 da Lei no 8.429), do direito tributário (arts. 168 e 174 do CTN), da ação popular (art. 21 da Lei no 4.717), entre várias outras leis.

EMENTA: Recurso Especial. Administrativo. Prescrição. A prescrição afeta o direito de o credor exigir parcelas do direito ao devedor, a decadência atinge o próprio direito. A prescrição pode ser arguida tanto pela Pública Adminis-

\footnotetext{
${ }^{9}$ Tribunal de Justiça de Minas Gerais. Apelação Cível nº 1.0000.00.237.752-1/00. Relator desembargador Almeida Melo. Quarta Câmara Cível. Diário da Justiça, 16 maio 2002.
} 
tração, como pelo servidor. Além do princípio da igualdade, o instituto visa resguardar das situações jurídicas. Conta-se tempo igual para ambos. ${ }^{10}$

Ainda nesse sentido e em respeito aos princípios constitucionais da igualdade e da isonomia, merece realce a Lei $n^{\circ}$ 9.494, de 10 de setembro de 1997,11 com a redação dada pela Medida Provisória n⿳ำ 2180-35/2001, que afirma no seu art. 1ํ-: "prescreverá em cinco anos o direito de obter indenização dos danos causados por agentes de pessoas jurídicas de direito público e de pessoas jurídicas de direito privado prestadoras de serviços públicos".

Assim, o legislador constitucional não conferiu ao instituto da imprescritibilidade a possibilidade de extensão a nenhum outro caso, senão aqueles previstos na Constituição, não autorizando ao legislador ordinário a instituir em nenhuma outra situação, "no Estado Constitucional e Democrático de Direito brasileiro, a regra geral; a imprescritibilidade é a exceção. Sendo assim, ressalvadas as duas exceções 'constitucionais', nenhuma outra pode ser criada pelo legislador 'infraconstitucional"', ${ }^{12}$

\section{Desvendando a ressalva do art. 37, §5ㅇ}

A norma constitucional deve ser interpretada de acordo com a natureza das coisas, respeitando o "ser" do "dever-ser", não cabe à Carta Magna a criação de ficções jurídicas, devendo estar ligada à realidade fática, sob pena de se tornar obsoleta, estéril e inaplicável, como define com muita propriedade o constitucionalista alemão Konrad Hesse (1991:14), ${ }^{13}$ o qual demonstra que a verdadeira vontade

\footnotetext{
${ }^{10}$ Superior Tribunal de Justiça. Recurso Especial no 136.204-RS/97.004.1207-5. Sexta Turma. Relator ministro Luiz Vicente Caernicchiaro. Diário do Judiciário da União, 21 out. 1997.

${ }^{11}$ Disciplina a ação civil pública de responsabilidade por danos causados ao meio ambiente, ao consumidor, a bens e direitos de valor artístico, bem público e dá outras providências. Diário Oficial da União. Brasília, 25 jul. 1985.

${ }^{12}$ Gomes, Luiz Flávio. Lei 9.271/96: o direito à prescritibilidade - a questão da retroatividade e as primeiras tendências jurisprudenciais. Goiânia, 2006. Disponível em: <www.tj.ro.gov.br>. Acesso em: 2 jul. 2007.

${ }^{13}$ Assevera Hesse (1991:14): "A norma constitucional não tem existência autônoma em face da realidade. A sua essência reside na sua vigência, ou seja, a situação por ela regulada pretende ser concretizada na realidade. Essa pretensão de eficácia não pode ser separada das condições históricas de sua realização, que estão de diferentes formas, numa relação de interdependência criando regras próprias que não podem ser desconsideradas. Devem ser contempladas aqui as condições naturais, técnicas, econômicas e sociais. A pretensão da norma jurídica somente será realizada se levar em conta essas condições. Se não quiser permanecer eternamente estéril, a Constituição não deve procurar construir o Estado de forma abstrata e teórica. Ela não logra produzir nada que já não esteja assente na natureza singular do presente. Se lhe faltam esses pressupostos, a Constituição não pode emprestar 'forma e modificação' à realidade; onde inexiste força a ser despertada - força essa que decorre da natureza das coisas - não pode a Constituição emprestar-lhe direção; se as leis culturais, sociais, políticas e econômicas imperan-
} 
da Constituição se manifesta naturalmente na ordem, sem desprezar a relevância e o significado de fatores reais do cotidiano, históricos, políticos e sociais.

À luz dos dogmas constitucionais, mostra-se indubitável a ocorrência da prescrição do direito nas ações de ressarcimento, repugnando-se qualquer interpretação extensiva em sentido contrário, haja vista se tratar de um instituto garantidor da segurança jurídica. Sendo a única exegese possível a de que as "respectivas ações de ressarcimento" ali referidas são as ações de regresso.

A expressão inserida, "ressalva", não pode ser desconsiderada, pois a lei não tem palavras inúteis e por isso deve ser interpretada de forma harmônica ao sistema jurídico.

\section{Da ressalva para ressarcir o erário}

O ordenamento jurídico atribuiu ao Estado o dever de "indenizar sempre que a atividade administrativa provocar dano" (Oliveira,1980:81), realizado pela gestão pública ou em seu nome. Contudo, é assegurado o direito de apuração interna do causador por culpa ou dolo de prejuízos causados a terceiros, sendo ainda assegurado o ressarcimento "contra o servidor que, nessa qualidade, tenha provocado o fato causador do dano indenizável, se agiu com culpa ou dolo" (Faria, 2001:531).

A ressalva referida no art. 37 do $\S 5^{\circ}$ se refere ao direito de regresso reservado ao Estado para se dirigir contra o agente, que no uso de sua função pública gerou prejuízos reclamados por terceiros.

O dano causado a terceiro, uma vez indenizado pelo Estado, gera a este o direito de regressar contra o servidor que por dolo ou culpa ensejou o prejuízo, de forma grave, não de forma absoluta, mas daquele que se locupletou indevidamente devido a uma prática ilícita. Por sua vez, sua ausência exclui a apreciação desse dispositivo, se sujeitando, por conseguinte, aos ditames da Lei de Improbidade Administrativa.

O §5º do art. 37 da Constituição, quando transcrito completando suas lacunas, tem clarificado seu entendimento, de onde se extrai:

A lei [de improbidade administrativa] estabelecerá os prazos de prescrição para ilícitos praticados por qualquer agente, servidor ou não, que causem prejuízos ao erário, ressalvadas as respectivas ações de ressarcimento [do

tes são ignoradas pela Constituição, carece ela do imprescindível germe de sua força vital. A disciplina normativa contrária a essas leis não logra concretizar-se". 
Estado condenado judicialmente por danos causados a terceiros, cabendo ação de regresso deste que ajuizada dentro do prazo legal de cinco anos contados do trânsito em julgado da sentença condenatória].

A garantia perseguida pelo $\S 5^{\circ}$ busca assegurar ao erário o direito de regresso contra o agente público que causou prejuízos a terceiros, cuja indenização o Estado arcou.

Uma vez identificada a responsabilidade civil de reparar o dano pelo Estado, cabe ao ente público o regresso nos casos de dano efetivo, como o locupletamento, ou de quaisquer outras ações dolosas, com vistas à recomposição econômica do patrimônio público, observados naturalmente dentro do prescricional de cinco anos contados do trânsito em julgado da sentença condenatória e indenizatória.

O direito de regresso também encontra apoio na Constituição Federal, no $\S 6^{0}$ do art. 37, e na Lei n⿳o 8.429/92, no art. 5ํ. Todos buscam o ressarcimento do erário por dano causado por terceiro ou agente público, mediante ação ou omissão, dolosa ou culposa. Ainda nesse sentido, o art. 23 (Lei no 8.429/92) estabeleceu o prazo de cinco anos para as ações destinadas a levar efeito às sanções nela previstas, a contar do término do exercício do mandato, cargo em comissão ou função de confiança, o que completa o entendimento do texto constitucional em debate.

EMENTA: Direito Administrativo e Processual Civil. Ação Ordinária de Ressarcimento de Danos. Improbidade Administrativa. Ministério Público. Legitimidade. Aspecto prescricional. A Constituição Federal de 1988, em seu artigo 129, III, ampliou o âmbito de atuação do Ministério Público, atribuindo-lhe legitimidade para a propositura de ação civil pública em defesa do patrimônio público. A lei que se aplica em questões processuais é a que vigora no momento da prática do ato formal, e não a do tempo em que o ato material se deu. $O$ artigo $37, \S 5^{\circ}$, da CF, prevê ressalva quanto às ações de ressarcimento por atos de improbidade administrativa, cuja interpretação pela imprescritibilidade mostra-se indiscutível. ${ }^{14}$

A questão da ressalva propriamente dita busca garantir ao Estado, independentemente da duração do debate judicial da ação instaurada em seu desfavor, a possibilidade de regresso contra o agente público que agiu com dolo ou culpa no desempenho de suas funções.

\footnotetext{
${ }^{14}$ Tribunal de Justiça de Minas Gerais. Apelação Cível nº 212861-9.00. Relator desembargador Célio Paduani. Quarta Câmara Cível. Diário da Justiça, 22 nov. 2001.
} 
Os prazos prescricionais nas ações de regresso estão sujeitos às mesmas faculdades da apuração da lesão direta e objetiva ao erário, sendo fundamental ter ocorrido o trânsito em julgado da ação movida em face do Estado, porque entre o fato gerador da responsabilidade civil do Estado por conduta comissiva ou omissiva do agente e o prazo de cinco anos para o ajuizamento da ação de regresso tem-se, em regra, um grande lapso temporal.

Uma vez apurada a responsabilidade do erário em indenizar o terceiro prejudicado pela ação do Estado, iniciará o decurso do prazo prescricional de cinco anos, consoante com a Lei de Improbidade Administrativa, para a apuração e propositura de ação de regresso ${ }^{15}$ contra o agente público responsável pela lesão que ensejou a indenização.

EMENTA: ADMINISTRATIVO E CONSTITUCIONAL. RESPONSABILIDADE CIVIL DO ESTADO. AÇÃO REGRESSIVA. DIES A QUO DE INCIDÊNCIA DO PRAZO PRESCRICIONAL: CONCRETO E EFETIVO PAGAMENTO, PELO ESTADO, DO VALOR A QUE FOI CONDENADO. Não há que se falar em ação regressiva sem o ocorrer de um dano patrimonial concreto e efetivo. A decisão judicial, trânsita em julgado, nada obstante possa refletir um título executivo para o Estado cobrar valor pecuniário a que foi condenado satisfazer, somente vai alcançar o seu mister se executada. Até então, embora o condenar já se faça evidente, não se pode falar em prejuízo a ser ressarcido, porquanto o credor tem a faculdade de não exercer o seu direito de cobrança e, nesta hipótese, nenhum dano haveria, para ser ressarcido ao Erário. O entender diferente propiciaria ao Poder Público a possibilidade de se valer da ação regressiva, ainda que não tivesse pago o quantum devido, em evidente apropriação ilícita e inobservância de preceito intrínseco à própria ação regressiva, consubstanciado na reparação de um prejuízo patrimonial. Demais disso, conforme a mais autorizada doutrina, por força do disposto no $\S 5^{\circ}$ do art. 37 da Constituição Federal, a ação regressiva é imprescritível. Recurso especial conhecido e provido (STJ, 2000). ${ }^{16}$

\footnotetext{
${ }^{15}$ De acordo com Faria (2001:533): “Um dos princípios da Administração Pública é o da indisponibilidade. Significa que o agente administrativo não pode dispor da coisa pública ao seu talante. As alienações ou outras transações de bens públicos são realizadas rigorosamente nos limites e formalidades estabelecidos em lei. Por isto, à autoridade não é facultado transigir quanto ao reembolso devido por servidor em virtude de dano causado a terceiro e indenizado pela entidade pública. $\mathrm{O}$ agente causador do dano deve ser acionado indistintamente. [...] A Lei Federal no 4.619, de 28/04/65, regula a ação regressiva da União contra seus servidores que, nessa qualidade, causarem danos a terceiro, que resultem em dispêndio para a Fazenda Pública Federal. A propositura da ação é obrigatória, no prazo de sessenta dias, contado da data do trânsito em julgado da decisão condenatória".

${ }^{16}$ Superior Tribunal de Justiça. Recurso Especial no 328.391/DF. Segunda Turma. Relator ministro Paulo Medina. Diário do Judiciário da União, 8 out. 2002, p. 274. RSTJ, v. 162, p. 198.
} 
Acredita-se, por tal motivo, que melhor do que a inserção do termo "ação de ressarcimento" ( $5^{\circ}$, art. 37), a Carta Magna poderia ter sido repetitiva ao fazer constar o termo "ação regressiva" no $\S 6^{\circ}$, ao contrário de "direito de regresso" ${ }^{17}$

\section{Conclusão}

O ordenamento jurídico pátrio, com o intuito de proporcionar a paz social e a segurança jurídica das relações de direito, privilegiou o entendimento de que imprescritibilidade é exceção à regra, entendendo como natural a prescrição nas ações de conhecimento em que se pleiteia a atribuição da eventual responsabilidade do agente em situação em que não existe valor líquido e certo a ser ressarcido.

Quando se fala em prescrição, se refere basicamente ao perecimento do direito de agir diante da inércia de seu titular durante determinado lapso temporal, em que todos indistintamente se sujeitam em inquestionável respeito aos princípios constitucionais da isonomia e da igualdade. Nesse sentido, o prazo prescricional aplicado em relação ao indivíduo também se aplica ao Estado e à Fazenda Pública.

O texto constitucional não diz expressamente que a ação de regresso é imprescritível, pelo contrário, expressa apenas uma ressalva, sem se aprofundar no assunto, tornando-se imperioso o reconhecimento que a imprescritibilidade é uma exceção à regra geral do prazo para o exercício do direito de ação, devendo sua aplicabilidade se sujeitar a uma interpretação sistemática e restritiva da norma, sob pena de inserir no ordenamento jurídico a inconstitucional possibilidade da eternização da pena, vedada expressamente no art. 5ํㅡ, em seu inciso XLIV e contrária aos preceitos apregoados pelos princípios e normas de direito fundamental.

Ainda que remotamente e a título acadêmico fosse considerada a possibilidade da ação de ressarcimento ser imprescritível, inexistiria instrumentação processual adequada para o seu exercício, uma vez que as ações processuais passíveis de aplicação possuem prazo limite de cinco anos para sua propositura, como ocorre no caso da ação civil pública e na ação popular, tidas como os meios processuais mais indicados para tutelar a defesa de direitos difusos, entre os quais se tutela a moralidade administrativa.

No caso da ação civil pública, apesar de o prazo não se encontrar explícito no texto da lei, repousa o entendimento de que diante de sua ausência aplica-se por analogia o prazo da ação popular, isto é, o prazo prescricional de cinco anos (disposto no art. $1^{\mathrm{o}}$ contido na Lei no $\left.4.717 / 65\right)$.

\footnotetext{
${ }^{17}$ Conforme Maria Goretti Bosco (2004:177): “A responsabilidade do Estado, por ato realizado pela Administração, ou por outrem em seu nome, nos moldes do art. 37, §6º , da Constituição Federal, tem natureza objetiva, assegurando o direito de regresso contra o agente público causador do dano, conforme a doutrina majoritária do direito brasileiro".
} 
A atenta leitura da CF/88, art. 37, $\S 4^{\circ}$, exprime o entendimento acerca das penalidades aplicadas às ações de improbidade. No mesmo espectro, o $\S 6^{0}$ permite a insurreição do Estado para responsabilizar o administrador público na condição de agente causador de danos a terceiros enquanto esse agir com dolo ou culpa no

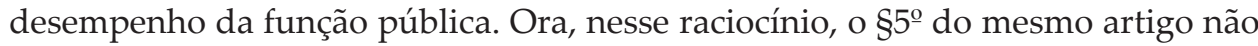
poderia destoar do tema improbidade, de modo que estabeleceu a prescrição objetiva para ilícitos praticados pelo administrador público, ressalvadas as ações de ressarcimento do erário movidas ante o direito de regresso.

Nesse sentido, o lapso temporal para o decurso de prazo das ações de regresso pelo erário tem o seu início de decurso de prazo a partir do trânsito em julgado da ação condenatória que atribuiu ao Estado o dever de indenizar o indivíduo prejudicado pela ação culposa ou dolosa do agente do Estado no desempenho de suas funções.

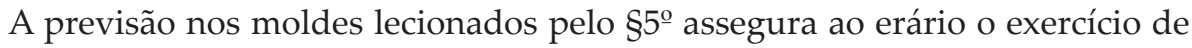
tal pretensão, sob a condição fundamental da existência inquestionável, líquida e certa do prejuízo suportado pelo erário diante do dano provocado pelo agente público a terceiro(s).

Dentro da estrutura processual, o direito de regresso do Estado somente é iniciado com a identificação da lesão provocada contra o terceiro, atribuída responsabilidade danosa ao agente público, dentro do prazo prescricional de cinco anos, contados efetivamente do trânsito em julgado que gerou o dever do Estado de indenizar.

Pelo exposto, conclui-se que é quinquenal o prazo prescricional do direito de ação do erário para postular judicialmente o ressarcimento e/ou o regresso contra eventuais prejuízos provocados direta ou indiretamente pela ação culposa ou dolosa do agente público no desempenho de suas atividades.

\section{Referências}

AMORIM FILHO, Agnelo. Critério científico para distinguir a prescrição da decadência. Revista dos Tribunais, São Paulo, v. 300. p. 7-8, 1960.

ANDRADE, Erico. O controle judicial da responsabilidade fiscal: ação civil pública de improbidade. Jurisprudência Mineira, Belo Horizonte, v. 165, p. 49, 2003.

ÁVILA, Humberto. Sistema constitucional tributário. 3. ed. São Paulo: Saraiva, 2008. - Teoria dos princípios - da definição à aplicação dos princípios jurídicos. 8. ed. Porto Alegre: Malheiros, 2008.

A distinção entre princípios e regras e a definição do dever de proporcionalidade. Revista Diálogo Jurídico, Salvador, Centro de Atualização Jurídica (CAJ), 
v. I, n. 4, jul. 2001. Disponível em: <www.direitopublico.com.br>. Acesso em: 1 dez. 2009.

BANDEIRA DE MELLO, Celso Antônio. Curso de direito administrativo. 13. ed. São Paulo: Malheiros, 2001.

BASTOS, Celso Ribeiro. Comentários à Constituição do Brasil. 2. ed. São Paulo: Saraiva, 2002. t. III.

BOSCO, Maria Goretti. Responsabilidade do agente público por ato de improbidade. Rio de Janeiro: Lumen Juris, 2004.

BRASIL. Superior Tribunal de Justiça. Disponível em <www.stj.gov.br >. Acesso em: 10 fev. 2010.

CANOTILHO, José Joaquim Gomes. Direito constitucional e teoria da Constituição. 2. ed. Coimbra: Almedina, 1998.

COSTA, Tito. Responsabilidade de prefeitos e vereadores. 4. ed. São Paulo: Revista dos Tribunais, 2002.

CRETELLA JR., José. Comentários à Constituição 1988. 2. ed. São Paulo: Forense, 2003. v. IV.

DALLARI, Dalmo de Abreu. Constituição e constituinte. São Paulo: Saraiva, 1985.

DINIZ, Maria Helena. Curso de direito civil brasileiro. 8. ed. São Paulo: Saraiva, 1991.

DI PIETRO, Maria Sylvia Zanella. Direito administrativo. 14. ed. São Paulo: Atlas, 2002.

FARIA, Edimur Ferreira. Curso de direito administrativo positivo. 4. ed. Belo Horizonte: Del Rey, 2001.

FERREIRA FILHO, Manuel Gonçalves. Comentários à Constituição brasileira de 1988. 2. ed. São Paulo: Saraiva, 1999. v. 1.

FERREIRA, Pinto. Comentários à Constituição brasileira. 2. ed. São Paulo: Saraiva, 1990. v. 1 e 2.

GOMES, Luiz Flávio Gomes. Lei 9.271/96: o direito à prescritibilidade - a questão da retroatividade e as primeiras tendências jurisprudenciais. Goiânia, 2006. Disponível em: <www.tj.ro.gov.br>. Acesso em: 10 jan. 2010.

HESSE. Konrad. A força normativa da Constituição. 2. ed. Tradução Gilmar Ferreira Mendes. Porto Alegre: Sérgio Antônio Fabris, 1991.

HORTA, Raul Machado. Direito constitucional. Belo Horizonte: Del Rey, 1999. 
LEAL, Antônio Luís Câmara. Da prescrição e da decadência. Rio de Janeiro: Forense, 1959.

MATTOS, Mauro Roberto Gomes. Da prescrição intercorrente no processo administrativo. Revista Ibero-Americana de Direito Público, São Paulo: América Jurídica, v. VI, 2002.

MAXIMILIANO, Carlos. Hermenêutica e aplicação do direito. 10. ed. Rio de Janeiro: Forense, 1988.

MEIRELLES, Hely Lopes. Direito administrativo brasileiro. 20. ed. Malheiros: São Paulo, 1995.

. Mandado de segurança. 25. ed. São Paulo: Malheiros, 2003.

MIRANDA, Pontes de. Tratado de direito privado. 6. ed. São Paulo: Revista dos Tribunais, 1971. v. VI.

MORAES, Alexandre de. Constituição do Brasil interpretada e legislação constitucional. São Paulo: Atlas, 2002.

NERY JÚNIOR, Nelson; ANDRADE NERY, Rosa Maria. Código de Processo Civil comentado. São Paulo: Revista dos Tribunais, 1999.

OLIVEIRA, José Carlos de. Responsabilidade patrimonial do Estado: danos decorrentes de enchentes, vendavais e deslizamentos. São Paulo: Edipro, 1980.

OSÓRIO, Fábio Medina. Direito administrativo sancionador. São Paulo: Revista dos Tribunais, 2000.

PACHECO, José da Silva. O mandado de segurança e outras ações constitucionais típicas. 4. ed. São Paulo: Revista dos Tribunais, 2002.

PAZZAGLINI FILHO, Marino et al. Improbidade administrativa. São Paulo: Atlas, 1998.

PEREIRA, Caio Mário da Silva. Instituições de direito civil. Rio de Janeiro: Forense, 1997.

SAVIGNY, Friedrich Karl von. Metodologia jurídica. Campinas: Edicamp, 2004.

SILVA, José Afonso da Silva. Curso de direito constitucional positivo. 9. ed. São Paulo: Malheiros, 2003.

SILVA, Paulo Márcio. Inquérito civil e ação civil pública. Belo Horizonte: Del Rey, 2000.

SILVA, De Plácido. Vocabulário jurídico. 12. ed. Rio de Janeiro: Forense, 1997. v. 8, p. 113.

TESSLER, Marga Barth. O exercício do poder de polícia e o prazo prescrito para a aplicação da sanção administrativa depois da Lei no 9873/99. Revista de Doutrina do Tribunal Regional Federal da 4⿳⺈ Região, n. 53, 2006. Disponível em: <www.revistade doutrina.trf4.gov.br>. 